\title{
ARTICLES
}

Submitted 09.07.2019 Approved 03.17.2020

Evaluated through a double blind-review process. Guest Scientific Editor: Andre Silva

Original version

DOI: http://dx.doi.org/10.1590/So034-759020200405

\section{MANDATORY IFRS ADOPTION, CORPORATE GOVERNANCE, AND FIRM VALUE}

\author{
Adoção obrigatória de IFRS, Governança Corporativa e Valor da Firma \\ Adopción obligatoria de las NIIF, gobierno corporativo y valor de firma
}

\section{JOELSON SAMPAIO ${ }^{1}$}

joelson.sampaio@fgv.br https://orcid.org/0000-00016560-2481

\section{HUMBERTO GALLUCCI²}

humberto.gallucci@unifesp.br

000-0001-7905-1879

\section{VINICIUS AUGUSTO BRUNASSI SILVA ${ }^{3}$}

vinicius.brunassi@fecap.br

0000-0002-1299-321X

\section{RAFAEL FELIPE SCHIOZER ${ }^{4}$}

rafael.schiozer@fgv.br

ORCID: 0000-0003-3890-6345

${ }^{1}$ Fundação Getulio Vargas, Escola de Economia de São Paulo, São Paulo, SP, Brazil

2 Universidade Federal de São Paulo, Departamento de Ciências Atuariais, São Paulo, SP, Brazil

${ }^{3}$ Fundação Escola de Comercio Alvares Penteado, Instituto de Finanças, São Paulo, SP, Brazil

4Fundação Getulio Vargas, Escola de Administração de Empresas de São Paulo, São Paulo, SP, Brazil

\begin{abstract}
We study whether financial and accounting disclosure affect firm value by focusing on the full adoption of International Financial Reporting Standards (IFRS) in Brazil in 2010. We compare firms with ex-ante lower accounting quality (firms in the Regular and Level 1 tiers of corporate governance) with otherwise similar firms that had already complied with higher-quality accounting standards (firms in the Level 2 and Novo Mercado tiers). IFRS adoption has a positive impact of approximately 30 percentage points on Tobin's $Q$ and 26 percentage points on market-to-book ratios for firms in the lower governance tiers, and substantially reduces the valuation gap between firms in the higher and lower tiers of corporate governance. This reduction in the valuation gap after IFRS adoption is explained by the relative increase in foreign ownership and stock liquidity of firms in the lower governance tiers.
\end{abstract}

KEYWORDS | IFRS, corporate governance, firm value, accounting quality, information asymmetry.

\section{RESUMO}

Estudamos se o nível de disclosure contábil e financeiro afeta o valor da firma, focando a adoção do padrão IFRS no Brasil em 2010. Comparamos firmas com pior qualidade contábil ex-ante (no nível regular e nível 1 de governança corporativa) com firmas similares que já adotavam o IFRS antes de se tornar mandatório (Nível 2 e Novo Mercado). A adoção do IFRS tem um impacto positivo de aproximadamente 30 pontos percentuais no $Q$ de Tobin e 26 pontos percentuais na razão entre valor de mercado e valor patrimonial para firmas nos níveis mais baixos de governança, e reduz substancialmente a diferença de valuation entre firmas nos níveis altos e baixos de governança corporativa. Essa redução na diferença de valuation é parcialmente explicada pelo aumento relativo na participação de estrangeiros no capital acionário e na liquidez das ações das firmas nos níveis mais baixos de governança corporativa.

PALAVRAS-CHAVE I IFRS, governança corporativa, valor da firma, qualidade contábil, assimetria informacional.

\section{RESUMEN}

Estudiamos si la divulgación financiera y contable afecta el valor de la empresa, considerando la implementación en Brasil de las Normas Internacionales de Información Financiera (NIIF) en 2010. Comparamos las empresas con una contabilidad de menor calidad (empresas en el Nivel Regular y Nivel, 1 niveles de gobierno corporativo) con empresas similares que ya cumplían con los estándares de contabilidad de mayor calidad (empresas en Nivel 2 y Novo Mercado). La adopción de las NIIF tiene un impacto positivo de aproximadamente 30 puntos porcentuales en la $Q$ de Tobin y 26 puntos porcentuales en la relación de precio/valor en libros para las empresas de gobierno corporativo de bajo nivel. La adopción de las NIIF también reduce sustancialmente la diferencia en la valoración entre compañías en los niveles más altos y más bajos de gobierno corporativo. Esta reducción en la diferencia de valoración después de la adopción de las NIIF se explica parcialmente por un aumento relativo en la propiedad extranjera y la liquidez de las acciones de las empresas en los niveles más bajos de gobierno.

PALABRAS CLAVE / IFRS, Gobierno corporativo, alor de la empresa, cualidad contabilidad, asimetría de la información. 


\section{INTRODUCTION}

International Financial Reporting Standards (IFRS) became mandatory for all Brazilian firms in 2010. We compare the heterogeneous effects of its adoption on firms with ex-ante low and high standards of corporate governance and conclude that IFRS decreased the pre-existing valuation gap between the two firm types.

Numerous studies have focused on the economic consequences of increased firm financial disclosure. In particular, the European Union's (EU) 2005 adoption of IFRS has become a popular area of inquiry (see George, Li, and Shivakumar (2016) for a thorough review of IFRS adoption studies). However, the benefits of IFRS may not be fully assessed because most studies have examined their adoption effects in countries where the existing information environment was already rich. In addition, the EU required pre-approval by the European Commission for any changes in reporting standards that were to be mandatorily enforced. This has resulted in piecemeal adoption of IFRS (KPMG, 2008) in the EU; therefore, changes in European firms' financial disclosure environment after 2005 do not fully capture the benefits of adopting IFRS.

The focus on Brazil aids identification for several reasons. First, IFRS represent a substantial improvement in accounting standards relative to the previous Brazilian generally accepted accounting principles (BRGAAP). Because Brazil's legal system is derived from Code law tradition, BRGAAP was strongly influenced by tax legislation and favored form over essence. Compared to BRGAAP, IFRS improved the information available to foreign investors by providing greater transparency and unifying accounting standards. IFRS adoption was enacted by Law 11,638 in 2007 and was implemented in a relatively short time compared to other jurisdictions. The law was passed in December 2007 and was followed by a "hybrid period" in 2008 and 2009 during which accounting practices gradually converged to IFRS (PelucioGrecco, Geron, Grecco, \& Lima, 2014), with full implementation in the first quarter of 2010.

Second, Brazil offers a set of firms with heterogeneous ex-ante accounting quality. Before the general IFRS adoption in Brazil, firms in the upper corporate governance tiers of the São Paulo Stock Exchange (Novo Mercado and Level 2) had better disclosure than firms in the lower tiers. Therefore, IFRS adoption results in greater improvement in transparency and disclosure for lower-tier firms than upper-tier firms. These two features allow for variation in accounting quality, both cross-sectionally (i.e., between firms), as well as through time, allowing for a better identification strategy. Finally, the focus on a single country eliminates micro and macroeconomic cross-country differences that might otherwise confound empirical identification.

Uniform standards such as IFRS reduce information asymmetry. We analyze the efficacy of these standards by studying the decrease in the existing value discrepancy among Brazilian listed companies under different corporate governance requirements before IFRS adoption. In 2000, the São Paulo Stock Exchange created three special governance listing tiers (Level 1, Level 2, and Novo Mercado) to improve governance practices and differentiate firms listed in the special governance tiers from regular listed firms. Firms listed in the Novo Mercado present the highest corporate governance standards, while companies listed in Level 2 have most of the Novo Mercado requirements, except they are allowed to have non-voting shares. All firms with Level 2 and Novo Mercado status were required to use IAS/IFRS starting in 2000. Firms listed in Level 1 and the Regular level were not subject to this mandatory requirement and were able use BRGAAP until 2007.

The passage of the law in 2007 required all publicly traded firms to adopt IFRS, but this change affected only the required reporting practices for Level 1 and Regular-level (hereafter "treated") firms because firms in the Novo Mercado and Level 2 tiers ("untreated" firms) had already adopted IFRS. Therefore, this law offers a quasi-natural experiment design: providing a source of variation in disclosure that is heterogeneous across firms and almost exogenous.

Our results show that mandatory adoption of IFRS has a positive impact on Tobin's $Q$ and the market-to-book ratio for firms with ex-ante lower disclosure quality. As Graphs 1 and 2 suggest, implementing IFRS almost completely eliminates the pre-existing valuation gap (Tobin's $Q$ and market-to-book ratio) between firms in the upper and lower corporate governance tiers. Our tests confirm that the differential reduction in Tobin's $Q$ and the marketto-book ratio is statistically significant, with magnitudes as large as 30 and 26 percentage points, respectively (corresponding to approximately $20 \%$ of the pre-shock measures of these variables). This result is consistent with that of Black, Carvalho, Khanna, Kim and Yurtoglu (2017), who find that a one-standard-deviation increase in disclosure predicts a $19 \%$ increase in Tobin's Q. Our matching estimators assure the comparison is made between treated and untreated firms that are otherwise similar in terms of observable features such as industry, size, and leverage.

We also present evidence on the mechanism that drives the decrease in the valuation gap between treated and untreated firms after IFRS adoption. First, we show that the difference in foreign investors' equity ownership between treated and untreated firms is significantly reduced after IFRS adoption. Nenova (2003) points to low accounting standards as one of the weaknesses inhibiting 
foreign investments in Brazil. IFRS adoption provides a set of standards that allow foreign investors to acquire information more efficiently (Amiram, 2012). Second, we find the difference in stock liquidity also declines after IFRS adoption.

\section{Graph 1. Median Tobin's Q}

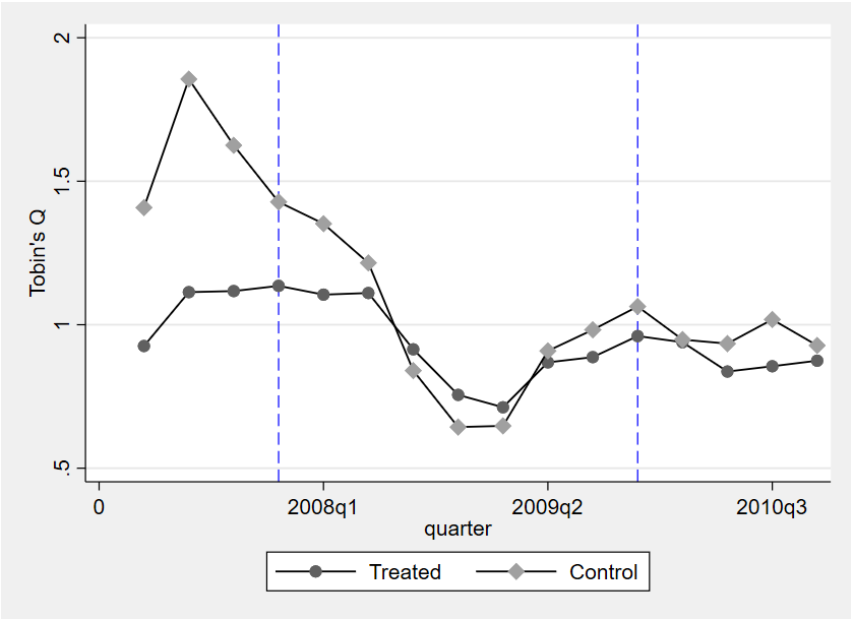

Note: Quarter median for each group. Tobin's Q is winsorized at the $5 \%$ level. Treated are firms in Regular and Level 1 governance tiers; Non-treated are firms in Level 2 and Novo Mercado governance tiers. Sample comprises 76 treated and 76 control firms.

\section{Graph 2. Median market-to-book}

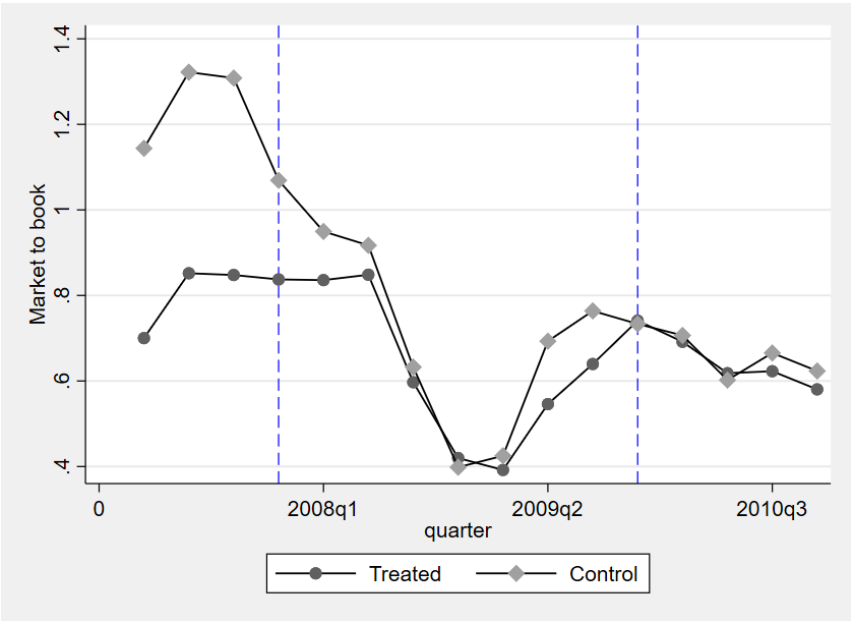

Note: Quarter median for each group. Market-to-book is winsorized at the $5 \%$ level. Treated are firms in Regular and Level 1 governance tiers; Non-treated are firms in Level 2 and Novo Mercado governance tiers. Sample comprises 76 treated and 76 control firms.

These two pieces of evidence are consistent with the notion that controlling shareholders of treated (low-governance-quality) firms were disincentivized to migrate to IFRS prior to its mandatory adoption because they could obtain private control benefits by using BRGAAP. Therefore, the smaller valuation gap between treated and untreated firms after IFRS adoption is plausibly related to controlling shareholders' reduced power to expropriate minority shareholders and debtholders. Therefore, our research adds to the literature that associates increased accounting disclosure with a decrease in expropriation by controlling shareholders.

This study contributes to the existing literature in at least two ways. First, it is the first study to investigate the interplay between corporate governance, accounting transparency, and firm valuation in an emerging market context. While several authors have examined the effect of accounting on valuation in developed economies (Armstrong, Barth, \& Riedl, 2010; Daske, Hail, Leuz, \& Verdi, 2008), and the relationship between corporate governance and accounting quality and transparency (Verrecchia, 2001; Verriest, Gaereminck, \& Thornton, 2012), this is the first study to link these three features in a quasi-natural experiment design in an emerging economy. Second, compared to previous work on the subject, the characteristics of the Brazilian market (full adoption of IFRS and ex-ante heterogeneity in accounting quality) offer a better empirical identification strategy for evaluating the effects of accounting transparency on firm value.

Our inferences withstand a number of robustness checks. A potential concern in our empirical strategy is that the period of IFRS adoption (2008 to 2010) partly coincides with the financial crisis. If the treatment assignment is correlated with macroeconomic variables that were affected by the crisis and are important for firm valuation (for example, if firms with better corporate governance are more exposed to shocks in the financial sector), the observed effect on valuation would be erroneously attributed to IFRS. We tackle this concern by checking whether operational and financial metrics (earnings, income, and leverage) were affected by the crisis differently for treated and untreated firms and find no significant differences between the two groups. Because the Brazilian Real suffered 30\% depreciation right after Lehman Brother's demise, we also use a placebo test to check whether firms in the two groups had different exposure to foreign currency, and find no evidence of difference. Moreover, we include controls in our estimations for a series of variables that have been found in the literature to affect firm valuation. Our results are consistent with previous literature.

Another possible concern in our identification strategy is that, before mandatory IFRS adoption, firms may have selfselected into the treatment and control groups; since firms could choose whether to comply with the Novo Mercado or Level 2 segment requirements, the treatment assignment may not be random. Our matching procedure ensures the firms we compare in the treated and control groups are otherwise similar. 
The remainder of the paper is organized as follows. The second section places our contribution in the context of related literature and describes the Brazilian institutional setting. The third section provides details about the data, while the fourth section explains our identification strategy. The fifth section presents the results, and the sixth section discusses the mechanism behind the change in valuation gap and a series of robustness checks. The last section concludes.

\section{Related Literature}

This study relates most closely to "association-based" studies in the financial literature on disclosure, which generally attempt to document the effects of reduced information asymmetry on trading volume, stock liquidity, and firm value (Kanodia, 2006). Previous theoretical and empirical research suggests a negative relationship between information asymmetry, trade volume, and stock liquidity (Admati \& Pfleiderer, 1988). For example, Leuz and Verrecchia (2001) consider voluntary commitment to increased disclosure levels in Germany. They find trade volume increases for firms that switch from German GAAP to IAS or US GAAP, suggesting disclosure decreases the information asymmetry component of the cost of capital. Similarly, Beatty, Chamberlain, and Magliolo (1996) find improvements in accounting quality are associated with lower contracting costs and less managerial rent extraction.

Previous research illustrates the benefits of higher levels of financial reporting quality. In general, improvements in accounting quality are related to a lower cost of capital and positive abnormal returns (e.g., Baiman \& Verrecchia, 1996; Barth, Konchitchki, \& Landsman, 2013; Daske, Hail, Leuz, \& Verdi, 2013; Diamond \& Verrecchia, 1991; Karamanou \& Nishiotis, 2005; Leuz \& Verrecchia, 2001). Botosan and Plumlee (2002) highlight that the firm implied cost of capital is negatively related to better governance practices, and Charitou, Karamanou, and Kopita (2018) find analysts' stock recommendations become more informative after IFRS adoption.

Daske et al. (2008) evaluate the economic consequences of mandatory IFRS adoption in an international setting. They show that market liquidity, equity valuation, and the cost of capital improved after IFRS adoption (market liquidity and equity valuation increased, whereas the cost of capital decreased). Lepone and Wong (2018) find IFRS adoption reduces the bidask spread of Australian stocks, and Charoenwong, Chong, and Wang (2014) show the relationship between asset liquidity and stock liquidity is reduced due to improved transparency after IFRS adoption.
According to Coffee (1984), Dye (1990), and Lambert, Leuz, and Verrecchia (2007), investors can better compare companies internationally due to IFRS reporting. Moreover, Verrecchia (2001) and Lambert et al. (2007) find higher-quality financial reporting and better disclosure help mitigate adverse selection problems.

In spite of improvements provided by better governance practices, Jeanjean and Stolowy (2008) point out that IFRS provide necessary but not sufficient conditions for creating a common business language. In addition, some investigators of reporting incentives, such as Ball, Kothari, and Robin (2000), Ball, Robin, and Wu (2003), and Daske et al. (2008), question the impact of better reporting policies. Santos, Schiozer, and Ponte (2019) show that country features, such as legal origin, law enforcement, and capital market scrutiny, are important determinants of the disclosure level, even years after IFRS implementation.

Effective IFRS implementation in firm reporting also plays an important role (Armstrong et al., 2010; Ball, 2006). Daske et al. (2008) show the cost of capital and Tobin's Q are affected by accounting rule changes. Verriest et al. (2012) explain that in a mandatory increased disclosure setting, compliance is associated with previous signs of higher-quality governance.

\section{IFRS and corporate governance in Brazil - institutional settings}

Our focus on a single country, Brazil, allows us to better identify the effects of IFRS on valuation. Under BRGAAP, receivables and payables were recorded at nominal value, whereas IFRS require that assets and liabilities be discounted to present value if material. Furthermore, BRGAAP did not distinguish between ordinary (voting) versus preferred (non-voting) shares. By contrast, under IFRS, a firm must calculate diluted earnings per share for ordinary shares, including dilutive potential (options and convertible instruments) if they meet certain criteria. Rodrigues, Schmidt, and Dos-Santos (2012) describe in detail the changes due to IFRS adoption and the changes it made in Brazil.

Previous authors analyze some effects of IFRS adoption in Brazil. Figlioli, Lemes, and Lima (2017) indicate reduced synchronicity levels (i.e., an increase in the proportion of company-specific information that affects returns) of shares traded after mandatory implementation of IFRS in Brazil, and Pelucio-Grecco et al. (2014) argue that IFRS implementation improves accounting quality by reducing earnings management, particularly for regulated companies. 
Silveira and Barros (2008) investigate the determinants of corporate governance in Brazil and find ownership concentration is negatively related to corporate governance levels. Black and Carvalho (2010) show that the São Paulo stock exchange created three high-governance listing tiers in 2000 with optional governance rules providing additional protection to minority shareholders. Black, Carvalho, and Sampaio (2014) show that creating the three high-governance listing tiers significantly improved investors' rights, ultimately resulting in a boom in initial public offerings in Brazil between 2004 and 2008. Most newcomers listed in one of the high-governance tiers, while some older companies adjusted procedures and bylaws, allowing them to migrate to higher corporate governance tiers. Previous research has also addressed the effect of corporate governance on firm value in Brazil before IFRS implementation. Silveira, Barros, and Famá (2003) find evidence that firms have higher values when the CEO is not the chairman.

Our study advances in these aspects and specifies an identification strategy for studying foreign investor shareholdings and improvements in stock liquidity after IFRS adoption. It stands out from previous studies as we examine the effects of improving accounting quality using a case where improvement is mandatory and uniformly applied across a well-defined set of firms. We use a quasi-natural shock and exploit the ex-ante distinction between the tiers' accounting standards requirements in Brazil. This setting allows us to identify the effects of IFRS adoption using a specific group of firms and to compare the effects of improved accounting standards on firm value by comparing these firms to otherwise similar (i.e., matched) firms that had already adopted IFRS. We follow Klapper and Love (2004), Durnev and Kim (2005), and Black et al. (2014), and use Tobin's Q as a proxy for firm value.

\section{DATA}

We collect financial statements and company information about Brazilian publicly listed firms from 2004 to 2015 from Economatica. Our main tests use data around the adoption of IFRS (between 2007 and 2010), while other periods are used for robustness and placebo tests. Table 1 provides the operational definitions of our financial variables.

We hand-collect firm ownership data from the Brazilian Securities and Exchange Commission (CVM). We analyze the Annual Information Report (IAN) and Reference Form (FR), which provide information about foreign investor stock ownership for every firm each year during our sample period. Finally, we collect bid-ask spread data (used to calculate liquidity measures) from Capital IQ.

\section{Table 1. Variable definitions}

\begin{tabular}{l|l}
\hline Tobin's $Q$ & $\begin{array}{l}\text { (book value of debt }+ \text { market value of } \\
\text { common stock)/ book value of assets }\end{array}$ \\
\hline Market-to-book & (market value of equity) / book value of assets \\
\hline In (assets) & natural logarithm of book value of assets \\
\hline Leverage & (Total debt)/total book value of assets \\
\hline Net Income/assets & (Net income)/total book value of assets \\
\hline EBIT/sales & (Earnings before interest and tax)/total sales \\
\hline PPE/sales & (Property, plant, and equipment)/Total sales \\
\hline EBIT/assets & $\begin{array}{l}\text { (Earnings before interest and tax)/total book } \\
\text { value of assets }\end{array}$ \\
\hline Industry dummies & Three-digit NAICS \\
\hline
\end{tabular}

Table 2 presents our sample selection procedure. Observations are excluded using the following filters: i) firms that changed corporate governance tiers during the sample period; ii) over-the-counter foreign firms listed as BDRs (Brazilian Depositary Receipts) and "Bovespa Mais" listed companies (firms similar to Novo Mercado, but smaller and with some restrictions); iii) firms in the Regular or Level 1 tiers with American Depositary Receipts (ADRs) and firms with any changes in ADR status, because these firms could arguably be subject to more strict disclosure requirements due to cross-listing; iv) firms facing financial reorganization; v) firms in NAICS sectors 522, 524, 525, and 551 (finance, insurance, and management companies); vi) companies without missing information in 2007 or 2010 . Our final sample consists of 132 companies, with 56 in the untreated group (Novo Mercado and Level 2) and 76 in the treated group (Level 1 and Regular tiers).

\section{Table 2. Process and sample selection}

\begin{tabular}{l|c}
\hline Number of firms in $\mathbf{2 0 0 7}$ & 444 \\
\hline Drop firms with: & \\
\hline $\begin{array}{l}\text { Changed corporate governance listing levels between 2007 } \\
\text { and 2010 }\end{array}$ & 1 \\
\hline BDR and OTC & 7 \\
\hline Regular or Level 1 firms with ADR & 14 \\
\hline NAICS Sectors 522,524,525, and 551 & 59 \\
\hline Firms facing corporate reorganization & 11 \\
\hline No sales information & 14 \\
\hline No data in 2007 and 2010 & 206 \\
\hline Total & 132 \\
\hline Novo Mercado and Level 2 firms (untreated firms) & 56 \\
\hline Level 1 and Traditional level firms (treated firms) & 76 \\
\hline
\end{tabular}

Note: Process and sample selection applied to Economatica data. 
We match pairs of firms in the treated and untreated groups based on their 3-digit industry classification, size, and leverage; there are 76 treated and 76 control companies. After this, our main sample includes quarterly information from the first quarter of 2007 to the fourth quarter of 2010. Our pairing/matching procedure is done with replacement, following Roberts and Whited (2013). Therefore, an untreated firm may be a match for more than one treated firm. In most of our empirical examinations, we use data from 2007 (prior to mandatory IFRS adoption) and 2010 (after full implementation of IFRS). We also perform a series of checks using the periods from 2006 to 2015.
Panel A of Table 3 presents the descriptive statistics for the main variables of interest, splitting the sample into treated firms (i.e., firms from Level 1 and Regular corporate governance tiers that were forced to adopt IFRS after 2007) and control firms (firms in Level 2 and Novo Mercado that adopted IFRS before 2007). We observe no striking differences between treated and control firms regarding these variables. Treated firms are only slightly smaller than control firms, with similar average levels of leverage, net income/assets, and EBIT/assets. Control firms have slightly higher average levels of PPE/sales and EBIT/sales. Panel $B$ of Table 3 shows the correlation matrix for these variables.

\section{Table 3. Descriptive statistics and correlation matrix}

\begin{tabular}{|c|c|c|c|c|c|}
\hline \multicolumn{6}{|c|}{ Panel A - Descriptive Statistics } \\
\hline Treated $(n=76)$ & Mean & Median & Standard Deviation & Minimum & Maximum \\
\hline $\ln$ (assets) & 14.04 & 13.88 & 1.99 & 10.46 & 17.78 \\
\hline Leverage & 0.25 & 0.23 & 0.14 & 0.00 & 0.61 \\
\hline Net Income/assets & 0.04 & 0.04 & 0.09 & -0.32 & 0.20 \\
\hline EBIT/sales & 0.15 & 0.11 & 0.23 & -0.42 & 0.94 \\
\hline PPE/sales & 1.44 & 0.81 & 2.31 & 0.12 & 11.23 \\
\hline EBIT/assets & 0.09 & 0.08 & 0.09 & -0.16 & 0.27 \\
\hline \multicolumn{6}{|l|}{ Control $(n=76)$} \\
\hline In (assets) & 14.60 & 14.53 & 0.99 & 12.60 & 16.74 \\
\hline Leverage & 0.25 & 0.23 & 0.14 & 0.00 & 0.45 \\
\hline Net Income/assets & 0.05 & 0.05 & 0.04 & -0.03 & 0.20 \\
\hline EBIT/sales & 0.21 & 0.12 & 0.30 & -0.48 & 0.74 \\
\hline PPE/sales & 2.24 & 0.81 & 2.89 & 0.12 & 11.23 \\
\hline EBIT/assets & 0.08 & 0.07 & 0.06 & -0.05 & 0.27 \\
\hline \multicolumn{6}{|c|}{ Panel B - Correlation Matrix } \\
\hline & In (assets) & Leverage & Net Income/ assets & EBIT/ sales & PPE/sales \\
\hline Leverage & $0.15^{*}$ & 1.00 & & & \\
\hline Net Income/assets & $0.35^{\star \star *}$ & -0.01 & 1.00 & & \\
\hline EBIT/sales & $0.27^{\star \star \star}$ & $0.45^{\star \star *}$ & $0.33^{* \star *}$ & 1.00 & \\
\hline PPE/sales & 0.01 & -0.05 & -0.14 & 0.11 & 1.00 \\
\hline EBIT/assets & $0.29^{\star \star \star}$ & $0.15^{\star}$ & $0.71^{\star \star \star}$ & $0.62^{\star \star \star}$ & $-0.21^{\star \star}$ \\
\hline
\end{tabular}

Note: This Table presents the descriptive statistics and correlation matrix for treatment and control groups. Both groups have 76 observations. The symbols *, ** and *** indicate statistical significance at $10 \%, 5 \%$, and $1 \%$, respectively.

\section{Identification Strategy and matching procedure}

We exploit the distinction between the listing tiers' accounting standard requirements. Level 2 and Novo Mercado tier firms were required to use IAS/IFRS starting in 2000, while Level 1 and Regular firms used Brazilian GAAP until 2007. The law required all publicly traded firms to adopt IFRS, but, in practice, required a change in reporting only for Level 1 and Regular firms (treated firms). 
Selection into governance tiers was originally made by the firms themselves, meaning group assignment is not random. However, firms' self-assignment into different corporate governance tiers seems unrelated to the passage of the law making IFRS mandatory for all Brazilian firms, because for most firms, tier assignment was made seven years before the law was passed. The long period between group assignment and law passage makes implausible the assumption that firms decided to comply with the higher governance tier requirements because they anticipated future mandatory IFRS adoption.

To further mitigate concerns about non-random assignment, we follow Almeida, Campello, Laranjeira, and Weisbenner (2011) and adopt a less parametric strategy that is more closely related to the notion of a "design-based" test. In this framework, we match firms in the treated group to otherwise similar firms in the control group to ensure treated and control observations belong to the same industry and have similar features along observable dimensions. We match treated to untreated firms using a propensity score technique based on industry (3-digit NAICS), size, and leverage as of the last quarter of 2007. We also perform alternative matching procedures using other covariates, such as net income/Assets, EBIT/sales, PPE/ sales, and EBIT/assets. We follow Angrist and Pischke's (2008) recommendation and use a parsimonious model containing only the covariates that actually predict the treatment. Because there are more treated than untreated firms in our sample, we match every treated firm to a single non-treated firm, following Almeida et al. (2011). We also follow Roberts and Whited's (2013) suggestion and use replacement in our matching procedure. After matching, the sample includes 76 treated and 76 control (untreated matched) firms.

Table 4 provides median comparison tests for our main covariates, following Almeida et al. (2011). We compare treated and control firms regarding within-firm changes in the matching variables (size and leverage), as well as net income/assets, EBIT/ assets, EBIT/sales, and PPE/sales as of the last quarter of 2007. These tests allow us to capture time-invariant heterogeneity by comparing within-firm changes in these variables. We find no significant differences between treated and control groups in the variable medians, suggesting our procedure successfully matched treated and control firms along these dimensions prior to the law passing.

\section{Table 4. Medians for treated and control firms in 2007}

\begin{tabular}{l|c|c|c|c|c|c}
\hline & In (assets) & Leverage & Net Income /Assets & EBIT/ Sales & PPE/ sales & EBIT/Assets \\
\hline Treated $(\mathrm{n}=76)$ & 13.88 & 0.23 & 0.04 & 0.11 & 0.81 & 0.08 \\
\hline Control $(\mathrm{n}=76)$ & 14.53 & 0.23 & 0.05 & 0.12 & 0.81 & 0.07 \\
\hline Difference & -0.65 & 0.00 & -0.01 & -0.01 & 0.00 & 0.01 \\
\hline Pearson's x2 statistic p-value & 0.42 & 0.87 & 0.63 & 0.87 & 0.87 & 0.63 \\
\hline
\end{tabular}

Note: Medians for Treated and Control Firms in 2007. The treated firms are defined as firms in the Regular and Level 1 segments at B3. Control firms are defined as firms in the Level 2 and Novo Mercado segments. The sample consists of 76 treated and 76 non-treated firms. The test for a difference in the medians of a firm characteristic across two groups is conducted by calculating the Pearson's $X_{2}$ statistic, with the p-values of this test reported at the bottom row of each column.

Inferences about the effect of IFRS on valuation (Tobin's Q and market-to-book value) are based on differences in the posttreatment outcomes of treated and control groups. We use the following specification:

$$
\begin{aligned}
& \text { Value }_{i, t}=\omega\left(\text { LowGov }_{i} \times \text { Póst }_{t}\right)+\tau \text { Póst }_{t}+\varphi \text { Low Gov }_{i}+\beta^{\prime} X_{i, t}+\varepsilon_{i, t} \\
& \text { Value }_{i, t}=\text { Tobin' }_{i, t} \text { or }_{\text {Market }_{i, t}}
\end{aligned}
$$

Low Gov $v_{1}$ is a dummy variable for treated firms (firms in the lower governance tiers), and Pós is a time dummy that equals 0 for 2007 and 1 for 2010. In alternative specifications, we use data from different years and Post equals o or 1 for different years.

$X_{i, t}$ is a matrix of pre-adoption control variables (size, leverage, net income/assets, EBIT/assets, EBIT/sales PPE/sales, and NAICS sector); and $\omega, \tau, \varphi$, and $\beta$ ' are parameters to be estimated. Our main coefficient of interest is $\omega$, and we refer to it as the ATT (average treatment on the treated) effect.

In all regressions, standard errors are clustered at the firm level, and robust to heteroskedasticity. 


\section{RESULTS}

Panel A of Table 5 presents our estimates of the average effects of IFRS adoption on the treated (ATT) firms, indicated by the coefficient $\omega$ in equation 1. Our estimate shows the ATT effect of mandatory IFRS adoption is a 0.301 increase in Tobin's Q, statistically significant at the $5 \%$ level. This effect is economically significant, as it corresponds to approximately $20 \%$ of the preshock mean value of Tobin's Q. We also estimate a positive ATT effect of 0.262 on the market-to-book ratio, equivalent to almost $20 \%$ of the mean pre-existing levels of the control group's marketto-book ratio; this result is statistically significant at the $10 \%$ level. These results are at the heart of our analysis of the effects of accounting practices on firm value. Since our matching procedure guarantees our treated and control groups are similar, we claim to find a causal relationship.

Because some IFRS features were adopted as early as 2008 , we also check for an immediate adoption effect by comparing the changes in our variables of interest for the treated and control firms between 2007 to 2008 . Our ATT estimates, reported in the third and fourth columns of Panel A, are only slightly smaller than our previous estimates.

The results for our control variables are consistent with the previous literature: firms with higher net income are more likely to have a higher Tobin's Q and market-to-book, as expected. In addition, we find a negative relationship between firm value and size, EBIT/sales, sales growth, and PPE/sales.

We test for a possible anticipation effect by setting the post-treatment dummy equal to 1 in 2007 and 0 in 2006 (first two columns), to verify if investors anticipate IFRS benefits for firm valuation before adoption. The results reported in Panel B of Table 5 show that more than half the Tobin's Q effect and almost all the market-to-book effect occurred as early as 2007 , even before low-governance firms actually adopted IFRS. In the third and fourth columns, we use data from 2007 (pre-treatment) and 2008 (post-treatment) and find the ATTs are positive, but not statistically significant at the usual levels. The fact that we observe an anticipation effect rules out the possible alternative explanation that the pre-existing differences between the valuation of high and low governance firms were simply due to different accounting procedures (IFRS versus BRGAAP).

The combined results in Panels A and B of Table 5 suggest investors anticipated the positive effects of IFRS on firm value, which may have happened for several reasons. The reduced likelihood of expropriation by controlling shareholders given the more stringent disclosure rules of IFRS or simply more transparency for foreign investors (we return to this point in the next section) are both plausible explanations.

We also perform a number of placebo checks, using different time windows for our treatment and alternative dates to match treated to control firms. Our ATT estimates are not statistically significant in any of these placebo tests, suggesting our results are not driven by unobservable features that simultaneously drive firm choice of corporate governance tier and valuation.

\section{CHANNELS REDUCING THE VALUATION GAP AND ROBUSTNESS CHECKS}

\section{Foreign stock ownership and stock liquidity}

We compare the share of foreign investor ownership for both groups of firms. We follow Colombo and Caldeira (2018) and hand-collect ownership structure from the CVM. The data provide information on ownership of investors with participation equal to or greater than $5 \%$ from each class of issued shares. We use this information to compute the proportion of foreign investor ownership for each share class of every firm each year.

We run the regression in Equation (1) using the proportion of foreign investor ownership as our dependent variable. The results are reported in Panel A of Table 6. Our estimates indicate foreign ownership of common (voting) shares of treated firms relative to control firms increases by approximately 19.3 percentage points between 2007 and 2010, which is statistically significant at the $10 \%$ level. In the first row of column 2, we use foreign ownership in all shares (voting and non-voting) instead of voting shares, and the effect is slightly smaller (16.3 percentage points). As shown in Table 6 , Panel C, untreated firms had more foreign ownership than treated firms as of 2007: 16 percentage points in common shares and 14 percentage points in total shares. We also check for the immediate effect of IFRS adoption by comparing the change in foreign ownership for treated and control firms from 2007 to 2008 . Our estimates, reported in the second column of Panel A, are slightly smaller than our previous estimates. IFRS adoption for low-governance firms is associated with an increase of approximately 13.9 percentage points in total foreign equity ownership (statistically significant at the $10 \%$ level). The coefficient for foreign common equity ownership is statistically insignificant, but its magnitude is comparable to the other coefficients in Panel A of Table 6. 
ARTICLES | MANDATORY IFRS ADOPTION, CORPORATE GOVERNANCE, AND FIRM VALUE

Joelson Sampaio | Humberto Gallucci | Vinicius Augusto Brunassi Silva | Rafael Felipe Schiozer

Table 5. Difference-in-differences tests - Tobin's Q and market-to-book

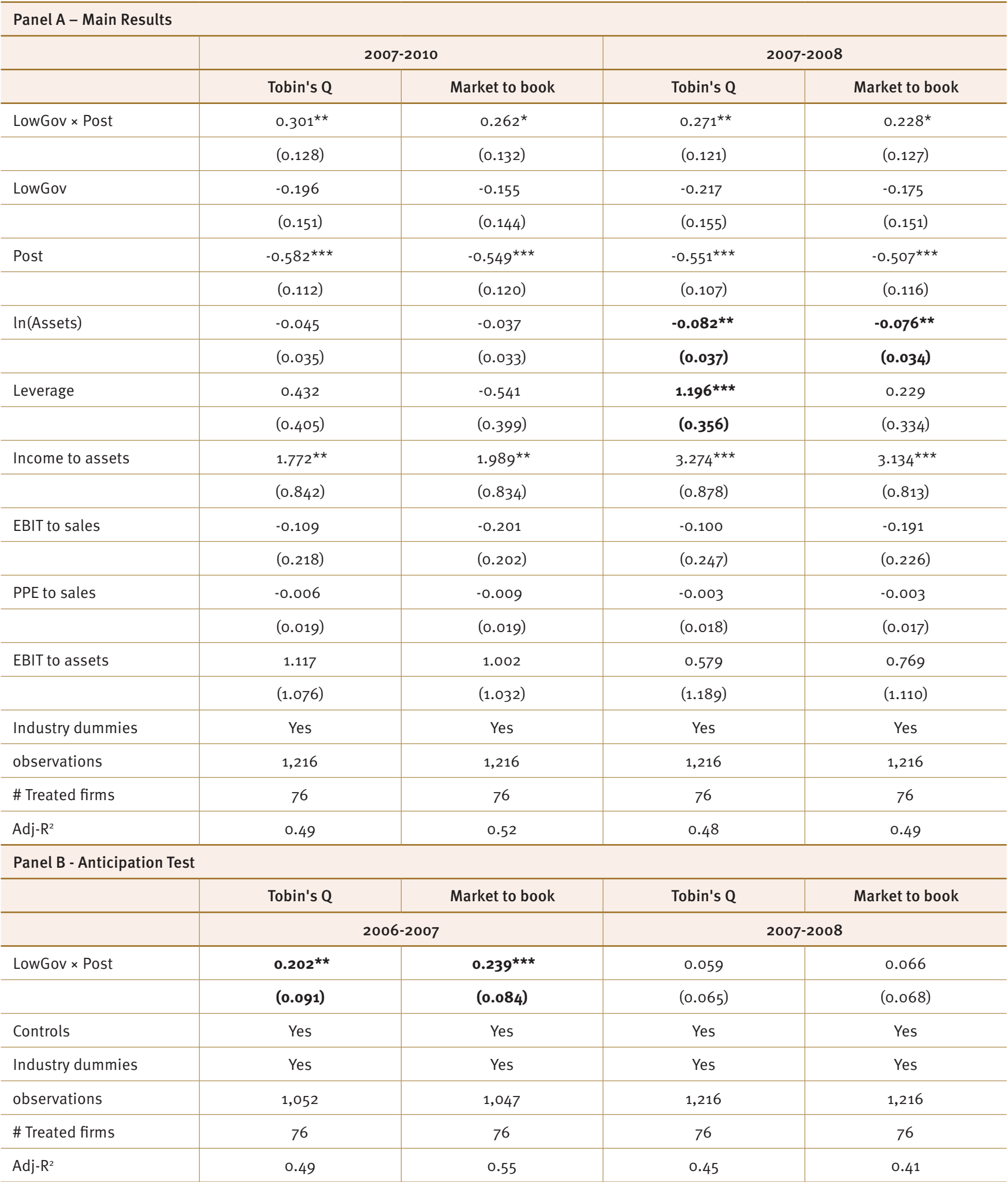

Note: This table presents the Difference-in-differences of firm Tobin's $Q$ and Market-to-book before and after the mandatory IFRS adoption in Brazilian firms. The control variables are: In(Assets), Leverage, Income to assets, EBIT to sales, PPE to sales and EBIT to assets. The symbols * ${ }^{* *}$ and *** indicate statistical significance at $10 \%, 5 \%$ and $1 \%$, respectively. 
ARTICLES | MANDATORY IFRS ADOPTION, CORPORATE GOVERNANCE, AND FIRM VALUE

Joelson Sampaio | Humberto Gallucci | Vinicius Augusto Brunassi Silva | Rafael Felipe Schiozer

Table 6. Difference-in-differences tests - Foreign investment, liquidity, and average differences between treated and control

\begin{tabular}{|c|c|c|c|}
\hline \multicolumn{4}{|c|}{ Panel A - Foreign Investment } \\
\hline & \multicolumn{2}{|c|}{$2007-2010$} & $2007-2008$ \\
\hline \multirow[t]{2}{*}{ Common Shares } & \multicolumn{2}{|c|}{$19.267^{*}$} & 16.487 \\
\hline & \multicolumn{2}{|c|}{$(11.169)$} & $(10.570)$ \\
\hline observations & \multicolumn{2}{|c|}{304} & 304 \\
\hline \# of treated firms & \multicolumn{2}{|c|}{76} & 76 \\
\hline Adj- $R^{2}$ & \multicolumn{2}{|c|}{0.24} & 0.24 \\
\hline \multirow[t]{2}{*}{ All Shares } & \multicolumn{2}{|c|}{$16.282^{\star}$} & $13.974^{*}$ \\
\hline & \multicolumn{2}{|c|}{$(9.221)$} & $(8.001)$ \\
\hline observations & \multicolumn{2}{|c|}{304} & 304 \\
\hline \# of treated firms & \multicolumn{2}{|c|}{76} & 76 \\
\hline $\mathrm{R}^{2}$ & \multicolumn{2}{|c|}{0.36} & 0.38 \\
\hline \multicolumn{4}{|c|}{ Panel B - Liquidity Measures } \\
\hline & \multicolumn{2}{|c|}{$2007 \times 2010$} & $2007 \times 2008$ \\
\hline \multirow[t]{2}{*}{ Bid-Ask Spread } & \multicolumn{2}{|c|}{$-0.017^{\star}$} & $-0.015^{\star}$ \\
\hline & \multicolumn{2}{|c|}{$(0.010)$} & $(0.009)$ \\
\hline observations & \multicolumn{2}{|c|}{981} & 971 \\
\hline \# of treated firms & \multicolumn{2}{|c|}{76} & 76 \\
\hline $\mathrm{R}^{2}$ & \multicolumn{2}{|c|}{0.47} & 0.43 \\
\hline \multirow[t]{2}{*}{ Amihud Illiquidity } & \multicolumn{2}{|c|}{$-4.127^{\star \star}$} & 1.434 \\
\hline & \multicolumn{2}{|c|}{$(1.825)$} & $(1.791)$ \\
\hline observations & \multicolumn{2}{|c|}{1.203} & 1.199 \\
\hline \# of treated firms & \multicolumn{2}{|c|}{76} & 76 \\
\hline $\mathrm{R}^{2}$ & \multicolumn{2}{|c|}{0.32} & 0.32 \\
\hline \multirow[t]{2}{*}{ Share Turnover } & & & $0.929^{* *}$ \\
\hline & & & $(0.454)$ \\
\hline observations & & & 1.216 \\
\hline \# of treated firms & & & 76 \\
\hline $\mathrm{R}^{2}$ & & & 0.51 \\
\hline Panel C - Average diff & & & \\
\hline Foreign ownership & 2007 & 2008 & 2010 \\
\hline Common Shares (pp) & -16.04 & -0.43 & 2.32 \\
\hline Total Shares (pp) & -14.06 & -0.70 & 1.69 \\
\hline Liquidity Measures & & & \\
\hline Bid-ask spread & 0.059 & 0.049 & 0.047 \\
\hline Amihud & 7.73 & 9.26 & 4.09 \\
\hline Share turnover & -1.21 & -0.29 & -0.68 \\
\hline
\end{tabular}

Note: Panel A presents the difference-in-differences of firm percentage of foreign investors (common shares and total shares) for each year. Panel B presents the difference in-differences of firms considering liquidity measures (Bid-Ask Spread, Amihud Illiquidity and Share Turnover). The control variables are: In(Assets), Leverage, Income to assets, EBIT to sales, PPE to sales and EBIT to assets. Panel C presents average difference for treated and control firms for each year (treated minus control firms). Variables for Foreign Investors are annual. Liquidity measures are the average of the original quarterly variables for each year. Difference between treated and control firms. Amihud variable is multiplied by $1,000,000$. The symbols ${ }^{*}, * *$, and $* * *$ indicate statistical significance at $10 \%, 5 \%$ and $1 \%$, respectively. 
Our results indicate the reduction in the valuation gap between firms from high and low corporate governance levels after mandatory IFRS adoption may be, at least in part, due to an increase in foreign investors' demand for low corporate governance firms. Accounting convergence allows foreign investors to improve firm monitoring, mitigating the expropriation by controlling shareholders. This evidence is also consistent with the pre-IFRS valuation gap between treated and untreated firms and explains why low-governance firms self-selected into not adopting IFRS prior to 2008.

To further investigate the channels that reduce the valuation gap, we analyze stock liquidity. This is not necessarily a separate channel from foreign ownership; in fact, it is plausible that increased foreign ownership improves stock liquidity. We calculate three different liquidity measures to evaluate market trading improvements due to IFRS adoption. First, we use Chung and Zhang's (2014) measure to obtain the closing percent quoted spread of stock $i$ on day $d$. The measure is specified as follows:

$$
\text { Spread }_{i, q}=\frac{1}{D} \sum_{d=1}^{D} \frac{A s k_{i, d}-B_{i d}}{M_{i, d}}
$$

where $A s k_{i, d}$ is the closing ask price of stock $i$ on day $d$, $B i d_{i, d}$ is the closing bid price of stock $i$ on day $d, M_{i, d}$ is the mean of $A s k_{i, d}$ and $B i d_{i, d}$ per quarter, and $D$ is the number of days in a quarter, as reported by Capital IQ. For dual-class shares, we use the most liquid. The closing percent quoted spread is the best spread proxy for capturing changes in effective and quoted spreads (Fong, Holden, and Trzcinka, 2017).

Second, we follow Amihud (2002) and measure stock illiquidity as the absolute percentage price change per dollar of daily trading volume. This ratio directly measures the impact of a monetary unit of trading volume on stock returns. The Amihud (2002) illiquidity ratio is defined as follows:

$$
V_{i, q}=\sum_{d=1}^{D_{i, q}} \frac{\left|R_{i, d, q}\right| / V_{i, d, q}}{D_{i, q}}
$$

where $R_{i, d, q}$ and $V_{i, d, q}$ are, respectively, the return and monetary trade volume of stock $i$ on day $d$ at quarter $q$, and $D_{i, q}$ is the number of days stock $i$ is traded in a quarter.

Finally, we compute the turnover ratio, which captures the average holding period of stocks (Atkins \& Dyl, 1997). It is defined as the ratio of the number of shares traded to the number of shares outstanding, and is computed as follows:

$$
\text { Turnover }_{i, q}=\sum_{d=1}^{D_{i, q}} \frac{\text { Vol }_{i, d, q} / \text { Share }_{i, d, q}}{D_{i, q}}
$$

where $\mathrm{Vol}_{i, d, q}$ is the trading volume for stock $i$ in day $d$ of quarter $q$, Share ${ }_{i, d, q}$ is the number of shares outstanding for stock $i$ in day $d$ of quarter $q$, and $D_{i, q}$ is the number of trading days for stock $i$ in quarter $q$.

Panel B of Table 6 presents the results of estimating Equation (1) using these three liquidity measures as our dependent variable. The first coefficient in the first row indicates the bidask spread of low-governance firms decreases by approximately 1.7 percentage points compared to high-governance firms after IFRS adoption (statistically significant at the $10 \%$ level). Most of this effect takes place immediately in 2008 , as shown by the coefficient of -0.015. In the second row of Panel B in Table 6, we report the results for the Amihud (2002) illiquidity measure (Eq. 4 ), which indicates the difference in stock liquidity of low versus high-quality governance firms decreases after IFRS adoption (statistically significant at the $5 \%$ level). However, the regression for the differential change in this measure between 2007 and 2008 yields statistically insignificant results.

Finally, the last row in Panel B of Table 6 shows the regression results using share turnover (Eq. 5) as the dependent variable. The coefficients are positive, as expected, but the ATT between 2007 and 2010 is statistically insignificant at the usual levels, whereas the ATT between 2007 and 2008 is statistically significant at the $5 \%$ level.

Taken together, the results in Table 6 confirm the decline in the valuation gap between low-and high-governance firms after IFRS adoption is at least partially explained by a reduction in the difference in foreign ownership and stock liquidity between the two groups of firms.

\section{Further robustness checks}

One concern is that high-governance firms are more sensitive to a financial crisis, due to omitted firm features, such as greater operational or financial exposure to global economic cycles than low-governance firms. We claim this is implausible for a number of reasons. First, industry-matching captures most of the sensitivity to business cycles. Second, to dismiss the concern that low-and high-governance firms may have different sensitivities to the crisis, we perform a series of difference-in-differences (DID) regressions in which we use operational and financial covariates as dependent variables. The logic behind these tests is that, if some unobserved 
firm feature causes treated and control firms to be heterogeneously affected by the crisis, we should observe different changes in operational and financial performance metrics around the crisis period. More specifically, we run the following regression:

$$
Y_{i, t}=y\left(\text { LowGov }_{i} \times \text { Post }_{t}\right)+\delta_{0} \text { Post }_{t}+\delta_{1} \text { BaixaGov }_{i}+\beta^{\prime} X_{i, t}+\varepsilon_{i, t}
$$

where:

$Y_{i, t}$ is one of the following variables: size, leverage, net income/assets, EBIT/assets, EBIT/sales, or PPE/sales.

LowGov ${ }_{i,}$ Post $_{t}$ and $X_{i, t}$ are previously defined, and $\gamma, \delta_{1}, \delta_{2}$, and $\beta$ are coefficients to be estimated.

Our main parameter of interest in the DID regression is $\gamma$. A non-significant $\gamma$ indicates that, for that particular dependent variable $Y$, the effect of the treatment between treated and control firms is homogeneous. The results in Table 7 report the coefficient $\gamma$ for the regressions estimated with each of the dependent variables. For example, the dependent variable in the first row of Table 7 is $\ln$ (assets). In the second row, it is the leverage ratio, and so on. The difference between the first and second columns of Table 7 is that the first column uses data from the four quarters of 2007 and 2010, whereas the second column uses data from

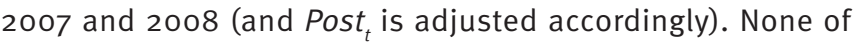
the coefficients reported in Table 7 are statistically significant, strongly suggesting treated and control firms do not have different sensitivities to the financial crisis, on average.

Table 7. Robustness checks - change in covariates

\begin{tabular}{|c|c|c|c|c|c|c|c|c|c|c|c|c|}
\hline & \multicolumn{2}{|c|}{ In(Assets) } & \multicolumn{2}{|c|}{ Leverage } & \multicolumn{2}{|c|}{ Income/assets } & \multicolumn{2}{|c|}{ EBIT/sales } & \multicolumn{2}{|c|}{ PPE/sales } & \multicolumn{2}{|c|}{ EBIT/assets } \\
\hline Coefficient & -0.144 & -0.082 & -0.064 & -0.033 & 0.001 & -0.003 & 0.029 & -0.005 & -0.085 & 0.108 & -0.012 & -0.001 \\
\hline standard error & $(0.117)$ & $(0.092)$ & $(0.047)$ & $(0.039)$ & (0.010) & $(0.005)$ & $(0.031)$ & $(0.031)$ & $(0.254)$ & $(0.308)$ & (0.009) & $(0.006)$ \\
\hline observations & 1,216 & 1,216 & 1,216 & 1,216 & 1,216 & 1,216 & 1,216 & 1,216 & 1,216 & 1,216 & 1,216 & 1,216 \\
\hline $\mathrm{R}^{2}$ & 0.69 & 0.71 & 0.45 & 0.52 & 0.66 & 0.65 & 0.73 & 0.74 & 0.73 & 0.68 & 0.80 & 0.80 \\
\hline
\end{tabular}

Note: This table presents the difference-in-differences of covariates before and after mandatory IFRS adoption in Brazilian firms.

Another confounding factor is the possibility that the different changes in firm valuation in the treated and control groups stem from their different sensitivities to the exchange rate. Because the Brazilian real appreciated approximately $25 \%$ from late 2007

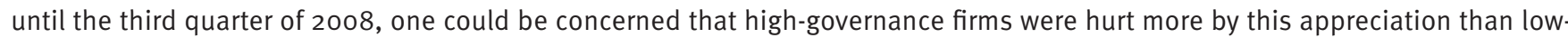
governance firms. We claim the results from our DID regressions in Table 7 help eliminate this concern, because any such difference in exchange rate exposure would show up either in firm income or EBIT in those regressions. However, to further mitigate this concern, we use the depreciation of the Brazilian Real in 2015 (when no change in accounting requirements took place) as an experiment. We split our sample into low (below median) and high (above median) Tobin's Q as of December 2014, and check if their valuation was affected differently by the depreciation of the Brazilian Real. Graph 3 shows that the median Tobin's Q of the two groups follows roughly parallel trends throughout the entire period, from 2014 to 2016, indicating firms with high and low Tobin's Q are similarly exposed to the exchange rate, on average. 


\section{Graph 3. Robustness Check - Median Tobin's Q and exchange rate shock}

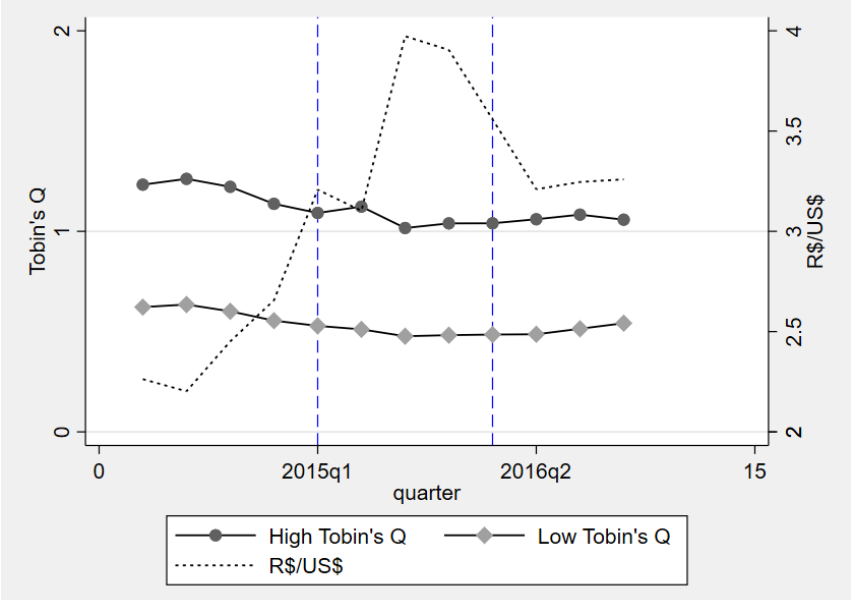

Note: This graphic presents the result of a sample split into high and low Tobin's Q firms during the 2015 Brazilian exchange rate depreciation.

Another concern might be that the untreated firms selected to serve as matches (control) have special features that cause selection bias, or that the matching procedure "artificially" attributes too much weight to specific control firms that appear more than once as a match for treated firms. To mitigate this concern, we run a series of DID regressions without matching. The coefficients of interest (not reported to conserve space) have the same order of magnitude as those in Table 5 and remain economically and statistically significant.

Finally, we perform a number of unreported robustness checks, such as changing the matching procedure and covariates and running regressions with and without firm-level and macroeconomic control variables. Our inferences withstand all these robustness checks.

\section{CONCLUSION}

This study investigates whether accounting transparency affects firm valuation. The focus on Brazil during mandatory IFRS adoption between 2008 and 2010 allows us to mitigate the endogeneity concerns present in cross-country studies, while taking advantage of the ex-ante heterogeneity in accounting quality and corporate governance of Brazilian firms. The Brazilian market's institutional features, such as low enforcement and the formalistic approach of the preexisting BRGAAP, results in a greater accounting transparency improvement after IFRS adoption compared to developed economies.
We use a matching technique that allows us to compare firm valuation between companies listed in the lower corporate governance tiers of the São Paulo Stock Exchange that had to adopt IFRS in 2008 to otherwise similar firms listed in the higher corporate governance tiers of the exchange, which had already adopted IFRS before it became mandatory. Our results indicate the improved transparency provided by IFRS adoption increases Tobin's $Q$ by as much as 30 percentage points and the marketto-book ratio by 26 percentage points, virtually eliminating the pre-existing valuation gap between firms listed in the high and low corporate governance tiers. We also show two channels that drive the reduction in the valuation gap: the reduction in the difference in foreign equity ownership and stock liquidity. We acknowledge, however, that given the very large magnitude of the effect of IFRS adoption on firm value (30 percentage points in Tobin's Q), there may be other channels at play.

Our results add to previous evidence that transparency improves firm value. While most previous studies rely on crosscountry heterogeneity in transparency, our identification strategy, which uses a quasi-natural experiment and matching techniques, allows us to better identify the causal relationship between accounting quality and firm value. Our inferences shed light on the role of regulation in providing transparency to protect minority shareholders. While our study does not directly investigate the reasons driving the pre-IFRS valuation gap between high-and low-governance firms, previous research shows this pre-existing gap may have been due to expropriation between controlling shareholders and minority shareholders. Because the decision not to adopt IFRS until required by law was essentially a choice by managers and controlling shareholders, we speculate this decision may have been driven by these players extracting private benefits from reduced transparency. Therefore, our findings suggest improving accounting quality mitigates expropriation and therefore improves minority shareholder returns.

Expropriation from minority shareholders by controlling shareholders is particularly relevant in emerging markets, where ownership tends to be more concentrated, non-voting shares are more common, and investor protection tends to be lower than in developed markets. To guarantee a healthy investment environment, regulators should focus on improving accounting quality and enforcing transparency rules.

\section{REFERENCES}

Admati, A., \& Pfleiderer, P. (1988). A theory of intraday trading patterns: Volume and price variability. Review of Financial Studies, 1, 3-40.doi: $10.1093 / \mathrm{rfs} / 1.1 .3$ 
Almeida, H., Campello, M., Laranjeira, B., \& Weisbenner, S. (2011). Corporate debt maturity and the real effects of the 2007 credit crisis. Critical Financial Review, 1, 3-58.doi: 10.3386/w14990

Amihud, Y. (2002). Illiquidity and stock returns: Cross-section and timeseries effects. Journal of Financial Markets, 5(1), 31-56. doi: 10.1016/ S1386-4181(01)00024-6

Amiram, D. (2012). Financial information globalization and foreign investment decisions. Journal of International Accounting Research, 11, 57-81.doi: 10.2308/jiar-50282

Angrist, J. D., \& Pischke, J.-S. (2008). Mostly harmless econometrics: An empiricist's companion. Princeton, NJ: Princeton University Press,1ed.

Armstrong, C. S., Barth, M. E., \& Riedl, E. J. (2010). Market reaction to the adoption of IFRS in Europe. The Accounting Review, 85(1), 31-61.doi: 10.2308/accr.2010.85.1.31

Atkins, A. B., \& Dyl, E. A. (1997). Transactions costs and holding periods for common stocks. Journal of Finance, 52(1), 309-325.doi: 10.1111/ j.1540-6261.1997.tbo3817.x

Baiman, S., \& Verrecchia, R. (1996). The relation among capital markets, financial disclosure, production efficiency, and insider trading. Journal of Accounting Research, 34, 1-22. Doi: http://hdl.handle. net $/ 10.2307 / 2491329$

Ball, R. (2006). International Financial Reporting Standards (IFRS): Pros and cons for investors. Accounting and Business Research, 36(1), 5-27.doi: $10.1080 / 00014788.2006 .9730040$

Ball, R., Kothari, S.P., \& Robin, A. (2000). The effect of international institutional factors on properties of accounting earnings. Journal of Accounting \& Economics, 29, 1-51. doi: 10.1016/S01654101(00)00012-4

Ball, R., Robin, A., \& Wu, J. (2003). Incentives versus standards: Properties of accounting income in four East Asian countries. Journal of Accounting \& Economics, 36, 235-270. doi: 10.1016/j. jacceco.2003.10.003

Barth, M. E., Konchitchki, Y., \& Landsman, W. R. (2013). Cost of capital and financial statement transparency. Journal of Accounting and Economics, 55, 206-224. doi: 10.1016/j.jacceco.2013.01.004

Beatty, A., Chamberlain, S., \& Magliolo, J. (1996). An empirical analysis of the economic implications of fair value accounting for investment securities. Journal of Accounting and Economics, 22, 43-77. doi: 10.1016/S0165-4101(96)00429-6

Black, B. S., \& Carvalho, A. G. de. (2010). Corporate governance in Brazil. Emerging Markets Review, 11(11), 21-38.doi: 10.1016/j. ememar.2009.09.004

Black, B. S., Carvalho, A. G. de, Khanna, V., Kim, W., \& Yurtoglu, B. (2017). Corporate governance indices and construct validity. Corporate Governance-An International Review, 25, 397-410.

Black, B. S., Carvalho, A. G. de, \& Sampaio, J. O. (2014). The evolution of corporate governance in Brazil. Emerging Markets Review, 20, 176 195. doi: 10.1111/corg.12215

Botosan, C., \& Plumlee, M. (2002). A re-examination of disclosure level and the expected cost of equity capital. Journal of Accounting Research, 40, 21-40. doi: 10.1111/1475-679X.00037

Charitou, A., Karamanou, I., \& Kopita, A. (2018). Are analyst stock recommendation revisions more informative in the post-IFRS period? Journal of Business, Finance \& Accounting, 45(1), 115-139. doi: $10.1111 / \mathrm{jbfa}$
Charoenwong, C., Chong, B. S., \& Yang, Y. C. (2014). Asset liquidity and stock liquidity: International evidence. Journal of Business Finance \& Accounting, 43(3), 435-468. doi: 10.1111/jbfa.12052

Chung, K. H., \& Zhang, H. (2014). A simple approximation of intraday spreads using daily data. Journal of Financial Markets, 17, 97-120. doi: $10.2139 /$ ssrn.1346363

Coffee, J. (1984). Market failure and the economic case for a mandatory disclosure system. Virginia Law Review, 70, 717-753. doi: $10.2307 / 1073083$

Colombo, J. A., \& Caldeira, J. F. (2018). The role of taxes and the interdependence among corporate financial policies: Evidence from a natural experiment. Journal of Corporate Finance, 50, 402-423.doi: 10.1016/j.jcorpfin.2017.09.007

Daske, H., Hail, L., Leuz, C., \& Verdi, R. (2008). Mandatory IFRS reporting around the world: Early evidence on the economic consequences. Journal of Accounting Research, 46, 1085-1142.doi: https://doi. org/10.1111/j.1475-679X.2008.00306.x

Daske, H., Hail, L., Leuz, C., \& Verdi, R. S. (2013). Adopting a label: Heterogeneity in the economic consequences of IFRS adoptions. Journal of Accounting Research, 53, 970-1080.doi: 10.1111/1475679X.12005

Diamond, D., \& Verrecchia, R. (1991). Disclosure, liquidity, and the cost of capital. Journal of Finance, 46, 1325-1360. doi: 10.1111/j.15406261.1991.tbo4620

Dye, R. (1990). Mandatory versus voluntary disclosures: The cases of financial and real externalities. The Accounting Review, 65, 1-24. doi: $10.2139 /$ ssrn.2010326

Durnev, A., \& Kim, E. H. (2005), To steal or not to steal: Firm attributes, legal environment, and valuation. Journal of Finance, 60, 1461-1493. doi: $10.1111 /$ j.1540-6261.2005.00767.x

Figlioli, B., Lemes, S., \& Lima, F. G. (2017). IFRS, synchronicity, and financial crisis: The dynamics of accounting information for the Brazilian capital market. Revista de Contabilidade e Finanças, 28(75), 326-343. doi: 10.1590/1808-057X201704450

Fong, K. Y., Holden, C. W., \& Trzcinka, C. A. (2017). What are the best liquidity proxies for global research? Review of Finance, 21(5), 13551401. doi: $10.1093 /$ rof/rfxoo3

George, E. T. De, Li, X., \& Shivakumar, L. (2016), A review of the IFRS adoption literature. Review of Accounting Studies, 21, 898-1004. doi: $10.2139 /$ ssrn.2664475

Jeanjean, T., \& Stolowy, H. (2008). Do accounting standards matter? An exploratory analysis of earnings management before and after IFRS adoption. Journal of Accounting and Public Policy, 27(6), 480-494 doi: 10.12691/jfa-3-3-3

Kanodia, C. (2006). Accounting disclosure and real effects. Foundations and Trends in Accounting, 1(3), 167-258. doi: 10.1561/1400000003

Karamanou, I., \& Nishiotis, G. (2005). The valuation effects of firm voluntary adoption of International Accounting Standards [Working Paper]. University of Cyprus. doi: 10.2139/ssrn.676328

Klapper, L. F., \& Love, I. (2004). Corporate governance, investor protection and performance in emerging markets. Journal of Corporate Finance, 10, 703-728. doi: 10.1016/Sog29-1199(03)00046-4

KPMG. (2008). Brazil and International Financial Reporting Standards, First-time adoption of IFRS: Answers to frequently asked questions. Retrieved from http://www.kpmg.com.br/publicacoes/audit/IFRS/ Folder_IFRS_Perguntas_Respostas_ingles_2506.pdf 
Lambert, R., Leuz, C., \& Verrecchia, R. (2007). Accounting information, disclosure, and the cost of capital. Journal of Accounting Research, 45, 385-420. doi: 10.1111/j.1475-679X.2007.00238.x

Lepone, A., \& Wong, J. B. (2018). The impact of mandatory IFRS reporting on institutional trading costs: Evidence from Australia. Journal of Business Finance \& Accounting, 45(3), 797-817. doi: 10.1111/ jbfa. 12320

Leuz, C., \& Verrecchia, R. E. (2001). The economic consequences of increased disclosure. Journal of Accounting Research, 38, 91-124. doi: $10.2307 / 2672910$

Nenova, T. (2003). The value of corporate voting rights and control: A cross-country analysis. Journal of Financial Economics, 68, 325-351. doi: 10.1016/S0304-405X(03)00069-2

Pelucio-Grecco, M. C., Geron, C. M. S., Grecco, G. B., \& Lima, J. P. C. (2014). The effect of IFRS on earnings management in Brazilian nonfinancial public companies. Emerging Markets Review, 21, 42-66. doi: 10.1016/j.ememar.2014.07.001

Roberts, M., \& Whited, T. M. (2013). Endogeneity in empirical corporate finance. Handbook of the Economics of Finance, v.2, Ch. 7 (pp. 493572), Amsterdam: Elsevier Publishing. doi: 10.1016/B978-0-44453594-8.00007-0
Rodrigues, L. L., Schmidt, P., \& Dos-Santos, J. L. (2012). The origins of modern accounting in Brazil: Influences leading to the adoption of IFRS. Research in Accounting Regulation, 24, 15-24. doi: 10.1016/j. racreg.2011.12.003

Santos, E. S., Schiozer, R. F., \& Ponte, V. M. R. (2019). Disclosure under IFRS: Does the legal origin disclosure gap persist for cross-listed firms? [Working Paper]. Retrieved from https://papers.ssrn.com/ sol3/papers.cfm?abstract_id $=2956918$

Silveira, A. D. M., \& Barros, L. A. B. C. (2008). Determinantes da qualidade da governança corporativa das companhias abertas brasileiras, Revista Eletrônica de Administração, 14(3), 512-540.

Silveira, A. D. M., Barros, L. A. B. C., \& Famá, R. (2003). Estrutura de governança e valor das companhias abertas brasileiras. Revista de Administração de Empresas, 43(3), 50-64. doi: 10.1590/Soo3475902003000300005

Verrecchia, R. (2001). Essays on disclosure. Journal of Accounting \& Economics, 32, 91-180. doi: 10.1016/S0165-4101(01)00025-8

Verriest, A., Gaereminck, A., \& Thornton, D. B. (2012). Corporate governance and properties of IFRS adoption [Working Paper]. Retrieved from http://www.econtrack.nl/uploads/document/ coporate $\% 2$ ogovernance $\% 2$ oand $\% 2$ oproperties $\% 200 f \% 20$ IFRS\%20Adoption.pdf

\section{AUTHORS' CONTRIBUTIONS}

The authors declare that they participated in all stages of development of the manuscript. From the conceptualization and theoretical-methodological approach, the theoretical review (literature survey), data collection (except professor Rafael Felipe Schiozer), as well as data analysis, and finally, writing and final review the article. 